Review

\title{
How to Study Protein-protein Interactions
}

\author{
Marjetka Podobnik, ${ }^{1}$ Nada Kraševec, ${ }^{1}$ Apolonija Bedina Zavec, ${ }^{1}$ Omar Naneh, ${ }^{1}$ \\ Ajda Flašker, ${ }^{1}$ Simon Caserman, ${ }^{1}$ Vesna Hodnik ${ }^{1,2}$ and Gregor Anderluh ${ }^{1,}$ \\ ${ }^{1}$ National Institute of Chemistry, Hajdrihova 19, 1000 Ljubljana, Slovenia \\ ${ }^{2}$ Department of Biology, Biotechnical Faculty, University of Ljubljana, Jamnikarjeva 101, 1000 Ljubljana, Slovenia \\ * Corresponding author: E-mail: gregor.anderluh@ ki.si \\ Tel: +386147602 61; Fax: +38614760300
}

Received: 09-03-2016

In memory of prof. dr. Janko Jamnik.

\begin{abstract}
Physical and functional interactions between molecules in living systems are central to all biological processes. Identification of protein complexes therefore is becoming increasingly important to gain a molecular understanding of cells and organisms. Several powerful methodologies and techniques have been developed to study molecular interactions and thus help elucidate their nature and role in biology as well as potential ways how to interfere with them. All different techniques used in these studies have their strengths and weaknesses and since they are mostly employed in in vitro conditions, a single approach can hardly accurately reproduce interactions that happen under physiological conditions. However, complementary usage of as many as possible available techniques can lead to relatively realistic picture of the biological process. Here we describe several proteomic, biophysical and structural tools that help us understand the nature and mechanism of these interactions.
\end{abstract}

Keywords: Molecular interactions. Yeast two-hybrid, Surface plasmon resonance, Microscale thermophoresis, Quartz crystal microbalance, Structural biology

\section{Introduction}

Molecular interactions involving proteins are fundamental for all living processes. Understanding of protein complex formation allows description of molecular functions and is, therefore, needed for the basic understanding of cellular processes. Furthermore, this knowledge on molecular interactions is important also for drug discovery and many experimental efforts have been recently invested into developing of small molecules that can affect protein complex formation. ${ }^{1-4}$ Molecular interactions are assessed by multitude of proteomic, biophysical, biochemical and structural methods (Figure 1). ${ }^{5,6}$ Each of these methods has their own advantages and drawbacks and in most cases only a combination of different methods can yield realistic description of molecular interactions that correspond to situation in vivo. ${ }^{5}$

Molecular interactions of proteins are diverse and are, according to the affinity, strong or weak. ${ }^{7}$ Strong interactions lead to long-lived protein complexes that can be assessed by some of the classical biochemical approaches such as size exclusion chromatography or native gel electrophoresis. ${ }^{8}$ Other methods are more appropriate for assessing transient interactions, such as some structural approaches, i.e. nuclear magnetic resonance (NMR) or small angle X-ray scattering (SAXS). Methods also differ by throughput and information content that can be provided (Figure 1). High-throughput methods can report interactions at large scale and can assess interactions globally at the cellular level, but they can be quite hard to perform. While they offer information on interactions at a relatively low resolution, basically just reporting the existence of particular intermolecular interactions, they provide a good and useful basis for further experimentation and analysis of molecular networks within cells or organelles. On the other hand, structural methods provide details at high resolution, all the way to the atomic level, and are thus very detailed and informative and provide essential information for designing molecular therapies aimed at protein complexes as targets. However, these methods are typi- 


\section{RESOLUTION}

\section{THROUGHPUT}

\section{PRESENCE OF INTERACTION}

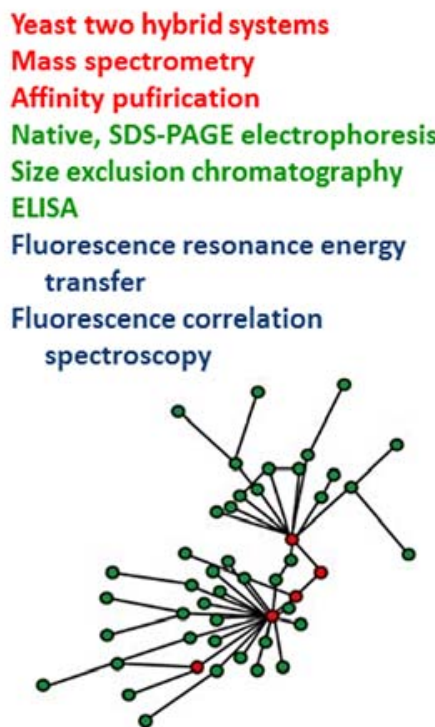

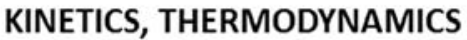

Surface plasmon resonance Isothermal titration microcalorimetry Quartz crystal microbalance Bio-layer interferometry Dual polarisation interferometry Microscale thermophoresis

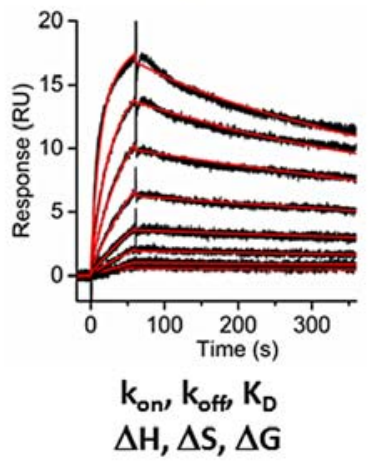

STRUCTURALINFORMATION

\author{
$\mathrm{X}$-ray crystallography \\ NMR \\ Cryo-EM \\ SAXS
}

Atomic force microscopy

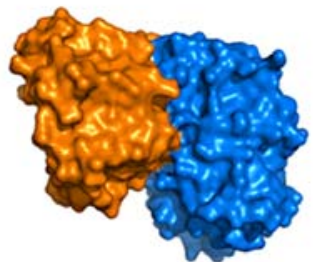

Proteomic approaches Biochemical approaches Biophysical approaches Structural biology

Figure 1. Methods for studying protein-protein interactions by throughput and information content. Some of the most commonly used methods for analysing protein-related interactions are listed. Typical data are presented for each methods assembly.

cally low-throughput, because of the high demands with regards to the quality of the sample and amounts of material needed for structural determination. Biophysical methods are somewhere in the middle. They can provide quantitative information on protein interaction, such as affinity rate constants or thermodynamic parameters from which equilibrium dissociation constant and free energy of binding can be derived (Figure 1).

In this review we will present some of the most commonly used methods for protein-protein interaction characterization with an emphasis on biophysical approaches that are most frequently used due to easier accessibility of the instrumentation. This review does not cover some other approaches that may be used for studying molecular interactions and we would like to highlight some other excellent manuscripts that can direct reader for further information. ${ }^{5-7,9}$

\section{Proteomic Approaches}

Proteomic approaches are used to assess molecular networks within cells or cellular compartments. Two most often used are affinity purification followed by mass spectrometry (AP-MS) and yeast two hybrid (Y2H) approaches, which can both assess thousands of interactions in a single study. Analysis of these requires computational approaches and genome-wide mapping. ${ }^{10}$ Well-developed databases store these information and are available for further data-mining in systems biology approaches. ${ }^{6}$ Other high-throughput genetic approaches have become popular in recent years, for example deep sequencing for quantifying protein variants after selection procedure that allow recognition of best binders in protein evolution studies. ${ }^{11}$

\section{1. Mass Spectrometry Coupled with Tandem-affinity Purification}

MS coupled with tandem affinity purification (TAP), TAP-MS, is one of the most effective strategies to isolate and identify protein complexes in a high-throughput manner. ${ }^{9}$ Historically, TAP was developed as a method to purify protein complexes expressed at physiological levels under normal conditions. The method relies on the use of two tags. It involves creation of a fusion of a protein of interest with a designed TAP tag, at the C- or N-end of the protein. TAP tag contains different combinations of two tags, separated with the protease (mostly tobacco etch virus protease, TEV) cleavage site. Various tags can be used, e. g. FLAG-tag, hemagglutinin, poly His, Strep, Myc, glutathione S-transferase, thioredoxin, protein A, protein $\mathrm{G}$, calmodulin binding peptide (CBP), chitin-binding domain, maltose-binding protein, or green fluorescent protein (GFP). Expression is allowed under the control of their endogenous promoters and production at physiological levels following by purification of proteins performed under native conditions. A protein of interest fused to TAP-tag is used as a bait to purify protein 
complexes that assemble on the TAP-tagged protein in vivo. Subsequently, these complexes are retrieved from the host by breaking the cells and binding to appropriate affinity resin, i.e. IgG matrix if one of the tags is protein A. After washing, TEV protease is introduced to elute the bound material at the TEV protease cleavage site next to protein A tag. This eluate is then incubated with another set of beads that bind the second tag on the fusion protein, for example CBP. This second affinity step is required to remove the TEV protease as well as traces of contaminants remaining after the first affinity step. ${ }^{12}$ After washing, the eluate consisted of the protein of interest bound to the interacting partners is then released with ethylene glycol tetraacetic acid (EGTA). ${ }^{13}$

Copurifying proteins from the bound complex can be determined in two complementary ways. Each purified protein preparation is electrophoresed on an SDS polyacrylamide gel, stained with silver, and visible bands removed and identified by trypsin digestion and peptide mass fingerprinting using matrix-assisted laser desorption/ionization-time of flight (MALDI-TOF) MS. In parallel, another aliquot of each purified protein preparation is digested in solution and the peptides are separated and sequenced by data-dependent liquid chromatography tandem mass spectrometry (LC-MS/MS) ${ }^{14}$ Machine learning can be used to integrate the mass spectrometry scores and assign probabilities to the protein-protein interactions. ${ }^{14} \mathrm{~A}$ variety of computational scoring pipelines have been developed to identify biologically relevant interactions among a large number of irrelevant interactions in raw TAP-MS data. Data can be characterized into four classes of protein-protein interactions: biologically relevant complexes occur in the cell; physically existing interactions as artefacts of sample preparation that do not occur in the cell (e.g., interaction of proteins from different compartments); interactions involving contaminant proteins; and physically non-existing interactions detected by an error. ${ }^{15}$ The results of TAP-MS experiments are networks. Cytoscape is a widely used tool for analyzing and visualizing these networks and a number of databases collect data from various types of protein-protein interaction experiments were launched. ${ }^{15}$ TAP-MS was successfully used to identify associated proteins to histones and new sites of post-translational modification, ${ }^{16}$ to provide global landscape of protein complexes in the yeast Saccharomyces cerevisiae, ${ }^{14}$ and to unravel the plant Arabidopsis protein cellular machinery complexes. ${ }^{17}$

TAP-MS allows determination of protein partners quantitatively in vivo without prior knowledge of complex composition. However, the chance for contaminants is reduced significantly, if there is some previous knowledge about interaction available. It is especially good method for testing stable protein interactions. It is considered to be easy to execute, often provides high yields in a throughput manner and has sufficiently low false-negative rate to allow for comprehensive studies of yeast genome. ${ }^{18}$ Howe- ver, special care should be invested in performing such experiments. Performing biological replicates of purifications is very important for the identification of robust interactions. They should be as different as possible from each other (different harvest date and/or cell clone, different batch of affinity purifications, different times and order for mass spectrometric analysis, etc.). In addition, proper negative controls should always be incorporated in every experiment. By contrast to samples, the controls must be kept as closely linked as possible to the biological samples they are associated with (i.e. harvesting, affinity purification, MS analysis, etc. done in parallel to the experimental sample). ${ }^{19}$ There is also a possibility that a tag added to a protein might hinder binding of proteins to their interacting partners and protein expression levels may also be affected. On the other hand, insufficiently exposed tags to the affinity matrices may also result in false results. Moreover, due to several washing rounds, it may not be suitable for identifying transient protein interactions.

\section{2. Yeast Two-hybrid System(s)}

Yeast two-hybrid (Y2H) system is a method that allows mapping protein-protein interactions in vivo, without a need to break up the cells The advantage of $\mathrm{Y} 2 \mathrm{H}$ system is that it can be carried out without specific equipment and can be automated. Therefore, many proteins can be screened in a high throughput manner against thousands of potentially interacting proteins in a relatively short time. ${ }^{20,21}$ The main weakness is a high number of false positive and false negative identifications. In order to minimize the number of false positive interactions the combination of multiple $\mathrm{Y} 2 \mathrm{H}$ vectors and protocols is recommended. ${ }^{20}$

The interaction between different proteins is conveniently monitored on plates by the activation of reporter gene, which leads to the changed phenotype of yeast colonies. The activation of reporter gene depends on the binding of a transcription factor (TF) onto an upstream activating sequence. The transcription factor consists of two fragments, binding domain (BD) and activating domain (AD) that cannot interact per se (Figure 2). The protein of interest is fused to $\mathrm{BD}$ and the construct is referred to as the bait protein; the other protein is fused to $\mathrm{AD}$ and the construct is referred to as the prey protein. The prey can be a single known protein or a library of proteins. Interaction of bait and prey complete TF and activates the reporter gene. The most efficient is the use of $\mathrm{Y} 2 \mathrm{H}$ system on systematic small-scale studies where the screen is performed using specific open reading frames. This kind of $\mathrm{Y} 2 \mathrm{H}$ is termed array-based $\mathrm{Y} 2 \mathrm{H}$ screening. However, $\mathrm{Y} 2 \mathrm{H}$ system is often applied also on a large scale, to large sets of proteins or even whole genomes where the screen is performed using genome or cDNA libraries. This kind of $\mathrm{Y} 2 \mathrm{H}$ is termed library-based $\mathrm{Y} 2 \mathrm{H}$ screening. The advantage of array-based $\mathrm{Y} 2 \mathrm{H}$ screening is the direct identification of interacting protein pairs. Library-based $\mathrm{Y} 2 \mathrm{H}$ scree- 
ning requires identification of individual prey clones and systematic retesting. ${ }^{22}$

$\mathrm{Y} 2 \mathrm{H}$ systems are available in a variety of different versions, with multiple different host strains, vectors, reporter genes, or protocols (Figure 2). The one-hybrid system enables detection of protein-DNA interactions. ${ }^{23}$ There is only one fusion protein constituted by a library, which is linked directly to the $\mathrm{BD}$ and $\mathrm{AD}$. The library is selected against the desired target sequence, which is inserted in the promoter region of the reporter gene. The three-hybrid system enables detection of RNA-protein interactions. ${ }^{24}$ The protein fusion domains cannot interact with each other and a hybrid RNA molecule is essential to connect the two domains. Classical Y2H screen is limited to soluble proteins and cannot be used for membrane proteins. However, in the split-ubiquitin system, two membrane proteins are fused to two different ubiquitin moieties. ${ }^{25}$ One of them is fused to a TF that can be cleaved off by ubiquitin specific proteases. When bait and prey interact, the two moieties assemble; the ubiquitin is recognized by ubiquitin-specific proteases, which cleave off the $\mathrm{TF}$ and reporter gene is transcribed. ${ }^{25}$ The fluorescent two-hybrid system uses two hybrid proteins that are fused to different fluorescent proteins (GFP, mCherry). Bait protein is fused to the lac represor (LacI). If bait and prey interact, they bring the fluorescent proteins in close proximity at the binding site of the LacI protein in the host cell genome, which is viewed as colocalization of both fluorescent proteins. ${ }^{26}$ Enzymatic two-hybrid system uses the detection of enzymatic activity. The example of this ver- sion of two-hybrid system is KInase Substrate Sensor (KISS), a mammalian two-hybrid system. ${ }^{27} \mathrm{Y} 2 \mathrm{H}$ in combination with next-generation sequencing has become an indispensable tool in analyzing large data sets in proteomics providing unique insights into human proteome and interactions between different proteins. ${ }^{28,29}$

\section{3. Fluorescence Resonance Energy Transfer}

Fluorescence resonance energy transfer (FRET) approach allows identification of molecular pairs at close proximity and is particularly suited for studies employing cells. FRET is a physical phenomenon of energy transfer from an excited donor-fluorophore to an acceptor-fluorophore. The transfer is non radiative and highly dependent on the distance between the two fluorophores. The transfer efficiency is inverse proportional to sixth power of the distance. ${ }^{30}$ Because of this, effective FRET can be a reliable proof of close proximity of binding partners in living systems. The interacting proteins labelled by either donor and acceptor fluorophores that exhibit effective energy transfer can indicate distance below $10 \mathrm{~nm} .{ }^{31}$ The fluorescent excitation-emission properties of an appropriate FRET fluorophore pair must have sufficiently distinct wavelength of their emitted light, which then allows efficient resonant energy transfer. ${ }^{32,33}$ The use of proteins genetically coupled to appropriate fluorescent proteins along with abilities of modern microscopes enable real time micro-imaging of interacting protein

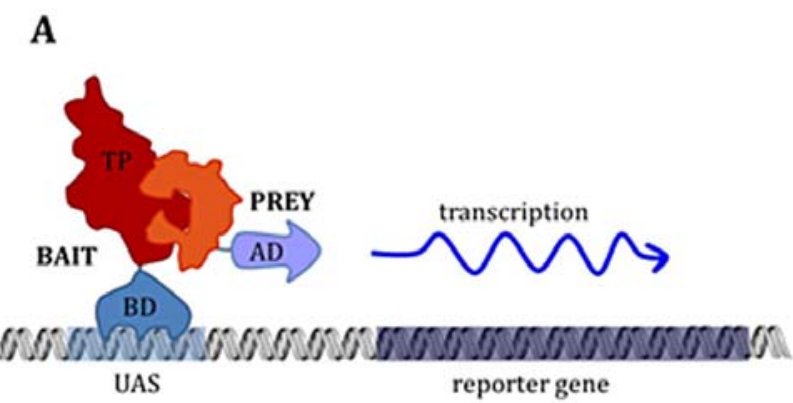

C

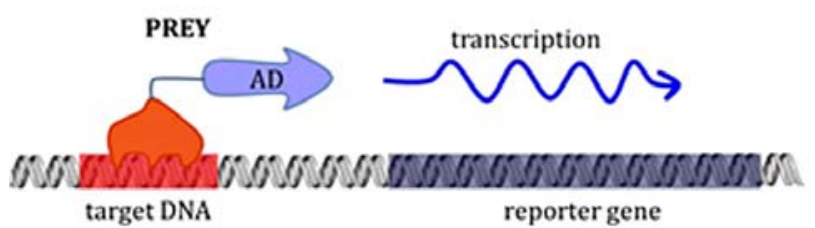

B

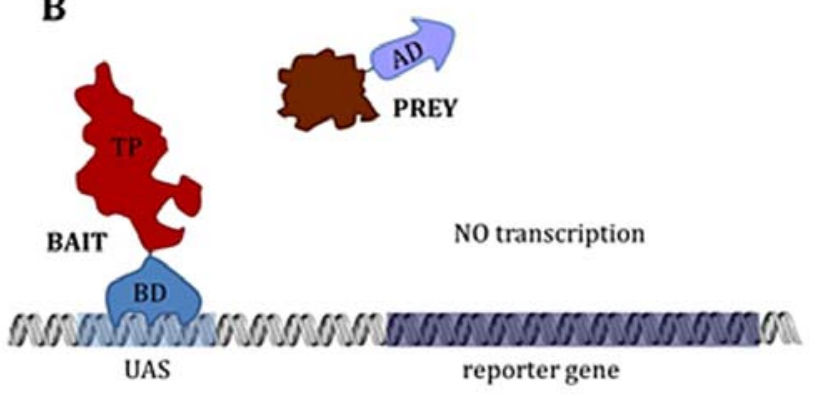

D

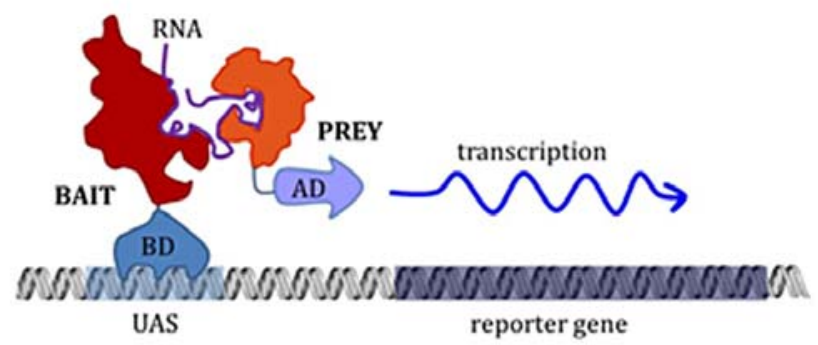

Figure 2. The study of protein-protein interactions using various Y2H systems. Target protein (TP) is fused to DNA-binding domain (BD), forming the bait protein (BAIT). Potential partner protein is fused to transcriptional activation domain (AD), forming the prey protein (PREY). When the two proteins interact (A), the bait recruits the prey to upstream activating sequence (UAS) and transcription of the reporter gene occurs. In the absence of interaction (B), transcription of the reporter gene is not present. Variants of Y2H system: one-hybrid (C) and three-hybrid system (D). 
partners in living cells. Ability of monitoring multiple interactions is needed to obtain good spatial and temporal resolution of the cellular processes, and this can be achieved by concomitant application of multiple fluorophores. ${ }^{33}$ Natural and genetically modified fluorescent proteins provide for many spectral options that can be used in living cells, however, they have several technical limitations like low stability and low light emission intensity as well as spectral overlapping with cell own auto-fluorescent molecules. ${ }^{31}$ Organic fluorescent dyes with superior properties can be conjugated to active proteins for studying processes in cell or at its surface. ${ }^{34,35}$ FRET imaging is also a powerful approach for identifying proteinlipid and protein-protein interaction in the cell membranes. The lanthanide based chelate fluorophores are another attractive advantage over organic or protein fluorophores. Their long fluorescence life-time enable time resolved imaging and further improving signal to noise ratio, however, lateral diffusion may interfere with results in membrane localization studies.

\section{Biophysical Approaches for Studying Molecular Interactions}

There is a plethora of biophysical approaches available that are relatively easy to perform and can provide quantitative data on molecular interactions. Quite a lot of them are optical approaches that exploit some physical phenomena occurring at the surfaces. These methods can therefore be divided by the need to immobilize one of the binding partners on the support, i.e. surface-based approaches, such as surface plasmon resonance (SPR) or enzyme-linked immunosorbent assay (ELISA), or those that can be assessed in solution, i.e. proximity-based assays, such as isothermal titration calorimetry (ITC) ${ }^{4}$ Furthermore, some methods require fluorescence labelling of one of the binding partners, as in microscale thermophoresis (MTS). Besides the availability of the instrumentation, the choice of a method also depends on the amount of the available protein sample of interest and its biochemical and biophysical properties, as well as of the availability and properties of the partner molecules (Table 1). In addition to protein-protein interactions, these biophysical methods can also be used for other binding partners like sugars, lipids, synthetic molecules, ions and others.

\section{1. Surface Plasmon Resonance}

Surface plasmon resonance (SPR) has become one of the most important optical-based approaches for studying molecular interactions. ${ }^{36-38}$ Binding of an injected molecule (termed analyte in SPR terminology) to a molecule (termed ligand) immobilized on the surface of a thin

Table 1. Advantages and disadvantages of some of the most commonly used biophysical methods for studying molecular interactions.

\begin{tabular}{|c|c|c|}
\hline Method & Advantages & Disadvantages \\
\hline $\begin{array}{l}\text { Surface } \\
\text { plasmon } \\
\text { resonance }\end{array}$ & $\begin{array}{l}\text { - Relatively fast } \\
\text { - Sensitive } \\
\text { - Low amount of sample } \\
\text { - Possibility to determine association } \\
\text { and dissociation rate constants } \\
\text { - Real time monitoring } \\
\text { - Label free }\end{array}$ & $\begin{array}{l}\text { - Immobilization of molecules required } \\
\text { - High-affinity interactions are not accessible } \\
\text { - Difficult to quantify weak binding interactions } \\
\text { - Influence of mass transfer effect } \\
\text { - High non-specific surface binding of some analytes } \\
\text { - Mass-detection limit }\end{array}$ \\
\hline $\begin{array}{l}\text { Isothermal } \\
\text { titration } \\
\text { calorimetry }\end{array}$ & $\begin{array}{l}\text { - Label-free } \\
\text { - Possibility to determine } \mathrm{K}_{\mathrm{D}} \text {, stoichiometry } \\
\text { and thermodynamics of the binding process } \\
\text { - Solution-based } \\
\text { - No molecular weight limitation } \\
\text { - Minimal assay development }\end{array}$ & $\begin{array}{l}\text { - High amount of a pure sample required } \\
\text { - Long preparation time } \\
\text { - High solubility of binding partners required } \\
\text { - Low to medium throughput } \\
\text { - Change in enthalpy upon interaction is a prerequisite } \\
\text { - Binding partners need to be soluble in the same } \\
\text { buffer system }\end{array}$ \\
\hline $\begin{array}{l}\text { Quartz } \\
\text { crystal } \\
\text { emicrobalanc }\end{array}$ & $\begin{array}{l}\text { - Setups that allow measurements } \\
\text { of interactions of molecules with exposed } \\
\text { binding partners on cells } \\
\text { - Allows assessing the physical nature of the } \\
\text { adsorbed molecules, i.e. flexibility and thickness } \\
\text { of the adsorbed film }\end{array}$ & $\begin{array}{l}\text { - Difficult quantification of results } \\
\text { - Immobilization of one of the binding partners } \\
\text { on the sensor surface required } \\
\text { - Low throughput }\end{array}$ \\
\hline $\begin{array}{l}\text { Microscale } \\
\text { thermophoresis }\end{array}$ & $\begin{array}{l}\text { - Fast } \\
\text { - Low sample consumption } \\
\text { - Ability to perform measurements in complex } \\
\text { samples, such as cell lysates } \\
\text { - Possibility of using it label-free }\end{array}$ & $\begin{array}{l}\text { - Modification of molecules with fluorescent } \\
\text { probes required } \\
\text { - Molecular behavior in thermophoretic field } \\
\text { is not well understood } \\
\text { - Quenching or photo-bleaching of labels } \\
\text { - Labels can affect the interaction of molecules }\end{array}$ \\
\hline
\end{tabular}


layer of gold-covered sensor surface (so-called sensor chip) changes the refractive index of the solution and this changes the resonance properties of surface plasmons, which is sensed by the detector. From the experimental data it is possible to derive binding and dissociation rates (kinetics), strength of an interaction (affinity), thermodynamic data, as well as determination of the active concentration of a protein without a need for a calibration curve. SPR is a non-invasive approach that requires small amounts of material and allows measurements in real time. It is relatively fast and does not require labelled molecules (Table 1).

SPR is the gold standard in academic and industrial settings, in which the molecular interactions have to be characterized. The most traditional type of interactions studied using SPR are those between two proteins, aimed to obtain affinity and kinetic data profile for two molecules for basic research or using this technique for medical diagnostics, environmental monitoring and food safety analysis. The ligand is typically covalently attached to the sensor surface by straightforward amine coupling (Figure 3 , left panel) or using some other approaches (thiol or aldehyde coupling), which enable more defined orientation on the sensor surface. In addition, surface can be further modified in a way that ligand can be captured exploiting some potential tags on a protein, like His-tag or biotin. After the immobilization the binding and dissociation of an analyte can be followed in real time (Figure 3, right panel). Typically, five concentrations of an analyte are injected over the ligand and obtained binding curves (termed sensorgrams) are fitted to an appropriate binding model. Between each sample injection one or two short regenera- tion pulses are usually required to clean the sensor chip and prepare it for the next cycle. This step largely depends on dissociation rates. ${ }^{39}$ Besides proteins it is possible to immobilize various lipid membrane systems and in this way study protein-membrane interactions and even elucidate mechanisms of pore formation for many important molecules. ${ }^{40-42}$ The method is often applied in drug discovery, since the technology has evolved enormously towards high-throughput instrumentation. Analysis of several hundred compounds can be resolved within half a day employing 384 wells microplates along with automated instruments. The first step for this application is usually structure- or ligand-based virtual screening yielding compound library to be tested in vitro. ${ }^{43,44}$ The SPR allows also assessing interactions of biomolecules with non-biologic surfaces.

Fast developing field of proteomics brought a need to develop SPR method even further. High-throughput SPR platforms are capable of analyzing large number of analytes in short time, especially by utilizing SPR imaging approach where the multiple interactions can be monitored simultaneously. ${ }^{45}$ The method can be connected with mass spectrometry to analyze unknown bound molecules. ${ }^{46}$ Extremely sensitive detection of femtomolar concentrations of analytes is possible due to development of new types of surfaces and employing ligands with high affinity. ${ }^{47}$ The methodology was further exploited in food safety program by developing biosensors for different types of toxins and artificial residuals in food. ${ }^{48,49}$ Since the first commercial SPR instrument has been launched 25 years ago these instruments became smaller, portable and easier to use with even improved
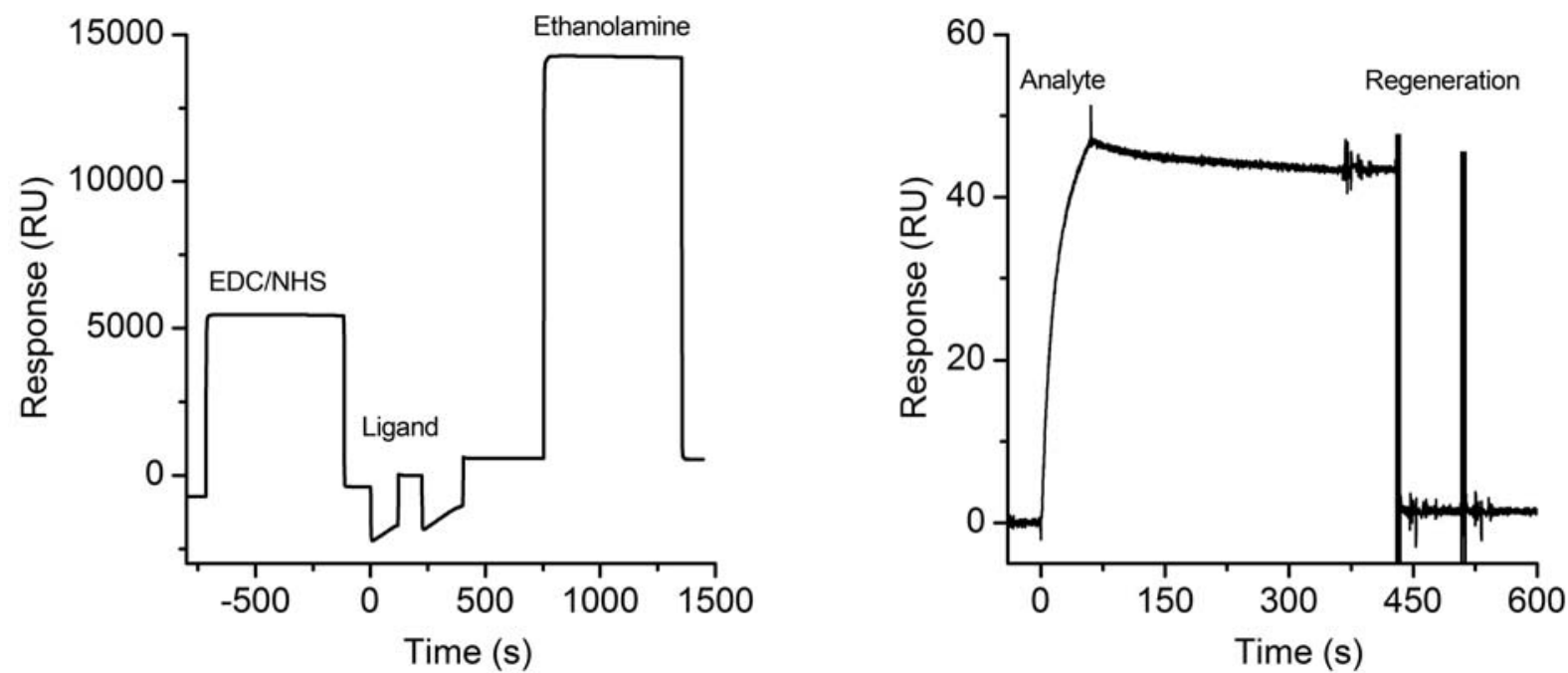

Figure 3. A typical SPR experiment. The left panel shows immobilization of one of the binding partners (ligand) to the surface of the sensor chip. The whole procedure is done through injecting solutions across the sensor chip. At the end of the process the ligand is covalently attached to the surface of the sensor chip, which is visible as the increase of the signal over the baseline value (compare starting signal level with the signal at the end). Right panel shows the typical experiment in which the second interacting molecule (analyte) is injected across the ligand. After the dissociation step, the regeneration procedure prepares the sensor chip surface for the next cycle. EDC, 1-ethyl-3-(3-dimethylaminopropyl)carbodiimide hydrochloride; NHS, N-hydroxysuccinimide. 
sensitivity and overall performance. The LSPR (localized surface plasmon resonance) instruments utilize gold nanoparticles instead of gold covered chips, making the LSPR sensors potentially applicable for an in situ detection changing the sensing capability by changing the shape, size, and material composition of the nanoparticles. One of the promising developments is the usage of graphene surfaces which enable large specific sensor surface, long-term stability and immobilization of varieties of biomolecules through covalent, noncovalent or electrostatic interactions. ${ }^{50}$

\section{2. Bio-Layer Interferometry}

Bio-Layer Interferometry (BLI) technology is another label-free optical approach suitable for measuring biomolecular interactions in real time. The BLI instrument shines white light onto the sensor surface and the reflected light is influenced by the interference from two surfaces: a layer of immobilized molecule on the biosensor tip, and the reference layer. When the analyte binds to the biosensor tip it causes a shift in the interference pattern. ${ }^{51}$ Since BLI detects only binding to the sensor surface, there is almost no interference from the sample buffer so the crude samples can be used with no cleaning step before starting the experiment. Using BLI the affinity and kinetics of various interactions can be determined, such as protein-protein, ${ }^{52}$ protein-nucleic acid $^{53}$ or binding of proteins to liposomes. $^{54}$

\section{3. Isothermal Titration Calorimetry}

Isothermal titration calorimetry (ITC) is a biophysical technique for measuring the formation and dissociation of molecular complexes. ITC measures the binding equilibrium by determining the heat evolved on association of a ligand with its binding partner. It works by directly measuring the heat that is either released or absorbed during a biomolecular binding event. ITC does not require any labeling of binding partners or immobilization and thus allows measurements of the affinity of binding partners in their native states. During ITC experiment, a complete thermodynamic profile of the molecular interaction can be obtained in a single experiment. Measurement of a heat transfer during binding enables accurate determination of the binding constant (association constant $\left(\mathrm{K}_{\mathrm{A}}\right)$ in $\mathrm{M}^{-1}$ units or dissociation constants $\left(\mathrm{K}_{\mathrm{A}}^{-1}\right.$ or $\left.\mathrm{K}_{\mathrm{D}}\right)$ with $\mathrm{M}$ units), the stoichiometry (n), and the enthalpy of binding $(\Delta \mathrm{H})$. The free energy $(\Delta \mathrm{G})$ and entropy $(\Delta \mathrm{S})$ of binding are determined from $\mathrm{K}_{\mathrm{A}}$. The temperature dependence of the $\Delta \mathrm{H}$ parameter, measured by performing the titration at varying temperatures, describes the heat capacity of binding $(\Delta \mathrm{Cp}) .{ }^{55}$ The ITC instrument is relatively simple. The microcalorimeter contains two cells, a reference cell filled with water, and the sample cell. Both cells are kept at exactly the same temperature. During the measurement, the ligand is titrated into the sample cell including the binding partner (i.e. protein) in a controlled manner. The heat sensing devices detect temperature difference between the cells when binding occurs and give feedback to the heaters, which compensate for this difference and return the cells to equal temperature. This direct measurement of the heat generated or absorbed when molecules interact and the quantity of heat measured is in direct proportion to the strength of binding. ${ }^{55}$

ITC is used in quantitative studies of a wide variety of biomolecular interactions, directly measuring millimolar to nanomolar affinities, and indirectly nanomolar to picomolar disassociation constants using competitive binding techniques. Besides binding affinities, ITC also elucidates mechanisms of molecular interactions. Information obtained from ITC experiments provides better understanding of structure-function relationships, as well as enables better planning in hit selection and lead optimization in drug design development. ${ }^{55}$ The range of interactions measured is very broad: proteins with small ligands ${ }^{56}$ (Figure 4), protein or peptide interactions with metals and ions, ${ }^{57}$

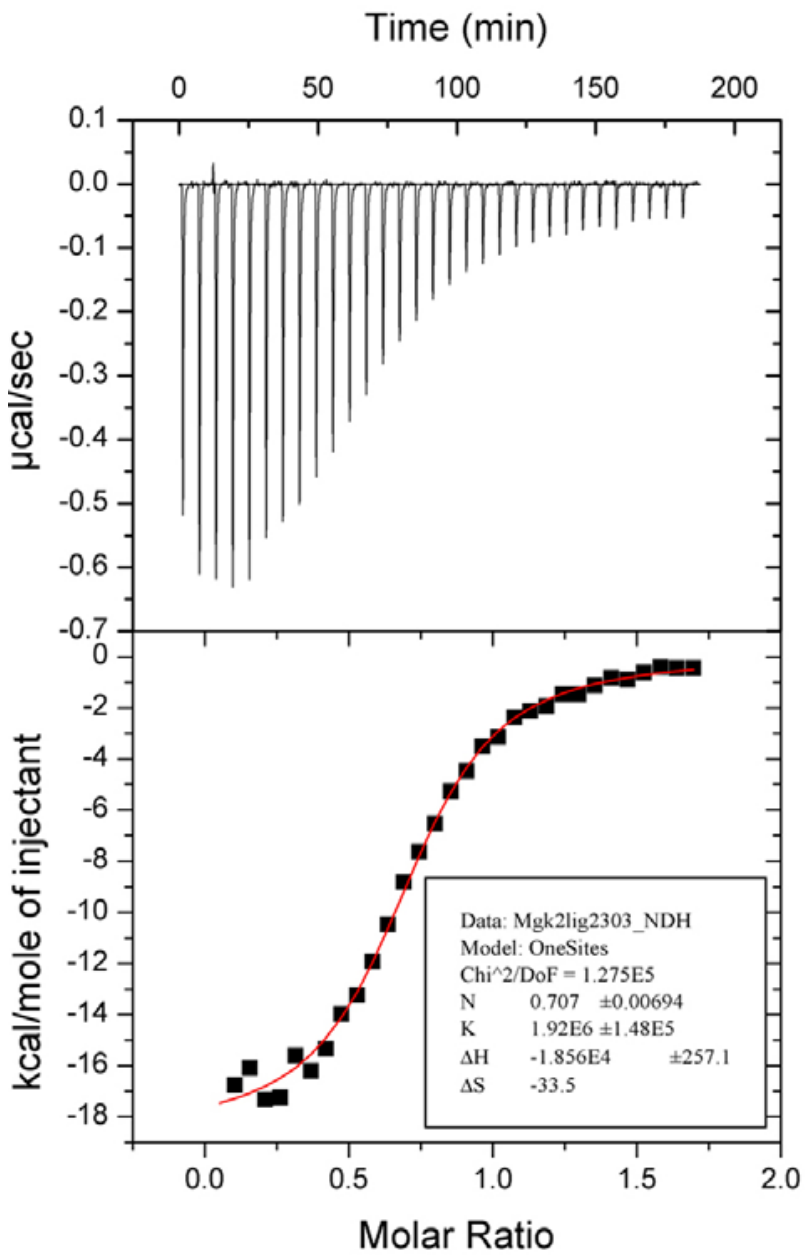

Figure 4. A typical ITC experiment using VP-ITC (MicroCal). Inositol hexakisphosphate kinase 2 was titrated with inositol hexakisphoshate. ${ }^{59}$ 
protein or peptide interactions with nucleic acids, lipid or membrane interactions, polysaccharide interactions, protein or peptide interactions with polymers and nanoparticles, nucleic acid interactions other than with proteins. In addition, ITC can measure enzyme activity and kinetics, small molecule ?interactions and micelle formation. ${ }^{58}$ While ITC is the best method for accurate quantitative measurements of interactions, one of the main drawbacks is a relatively large amount of sample needed for the experiment, in comparison with other biophysical approaches such as SPR or MST. However, the advent of the upgraded machines requiring significantly lower amounts of samples is gradually overcoming this problem.

\section{4. Quartz Crystal Microbalance}

The quartz crystal microbalance (QCM) is a high resolution mass sensor. The sensing mechanism is based on detection of changes in resonant frequency of the piezoelectric crystal resonator. It has been used in various environments, including biological systems. ${ }^{60,61}$ Rigidly deposited mass on the crystal surface results in proportional decrease of resonant frequency thus enabling straightforward analysis of measurements. ${ }^{60,61}$ The binding kinetic is recorded in a flow-through system as a sensograms of real time changes in sensor frequency versus time. Affinity rate constants can be derived from such data. Additionally, dissipation of the signal can be monitored. Less rigid deposits cause more rapid loss-dissipation of crystal oscillatory energy. From the dissipation signal thickness and viscoelastic properties of deposited layer can in addition be derived. This enables further elucidation of changes in the structure of deposited film of material including burst of membrane vesicles on the sensor surface as well as conformational changes of attached proteins. ${ }^{62,63} \mathrm{QCM}$ senses mass directly, therefore no labelling of studied material is needed. The sensor surface can be functionalized with capture molecules for specific detection of the selected analyte. Any unspecific binding of mass to the sensor result in biased results. To minimize these artefacts, two channel measurements are generally performed enabling subtraction of unspecific signal. Sensors can be prepared for interaction studies of ions, small molecules or proteins. ${ }^{63-65} \mathrm{QCM}$ can be set for detection of viruses and artificial particles or even for binding of cells from suspension. ${ }^{61,66,67}$ Interactions of proteins from complex samples such as culture media or sera can also be measured accurately as the optical properties of samples have no effect on the measurement enabling studies in biologically relevant environments. The method has been frequently used as a means of detection of specific disease related protein markers in serum. ${ }^{68}$ In addition to simple molecular binders the sensor surface can be decorated by complex structures like supported model lipid membranes or cell derived membranes enabling studies of membrane binders like pore-forming proteins and others. ${ }^{62,69} \mathrm{QCM}$ can de- tect protein interactions even if not in close proximity to the surface of the sensor. Multistep binding processes can be successfully monitored in real time. Proteins can be sequentially loaded in a complex structure and the process continuously monitored. ${ }^{70}$ Even adherent cells can be cultured on the sensor surface for testing of interaction with ligands. This allows monitoring of cell surface proteins interactions and physiological responses of cells, like release of micro-vesicle..$^{71,72}$

\section{5. Microscale Thermophoresis}

Although thermophoresis (Ludvig-Soret effect, thermodiffusion) was already described in $19^{\text {th }}$ century, it was only recently developed as a convenient tool for a description of biomolecular characteristics. The thermophoretic behavior of molecules, that is their vectorial diffusion along temperature gradient, is normally present in the nature as for e.g. in the circulation of air or ice. ${ }^{73}$ While the effect was generally found to be practical for the characterization or separation of some inorganic molecules or polymers, ${ }^{74,75}$ it has first been applied to biomolecular characterization in the last few years. Upon heating the spot of the solution of fluorescently labelled plasmid DNA with infra-red (IR) laser, Braun and Libchaber observed the depletion of fluorescence in the heated area. ${ }^{76}$ The cause for the fluorescence-drop was the movement of labelled molecules along the temperature gradient towards the colder part of the system. The salt-dependent diffusion of DNA along the temperature gradient suggested the new possible approach for the characterization and purification of nucleic acids. Usability of thermophoretic behavior of molecules for their characterization, was further shown with the analysis of aptamer DNA-thrombin interactions. ${ }^{77}$ The DNA is not the only biomolecule that can be applied to thermophoretic gradient for its characterization, as shown by the same group in the analyses of protein-protein and ion-protein binding. ${ }^{78}$ Since $\mathrm{nM}$ concentrations and low volumes ( $\mu$ l-range) of protein and DNA solutions were used in the analyses, the phenomenon was termed microscale thermophoresis (MST).

MST-based instruments track the movement of fluorescent molecules along the applied temperature field (Figure 5). Small volume ( $\sim 5 \mu \mathrm{l})$ of fluorescent molecule solution is applied to the glass capillary, which is placed into the instrument. The focused IR laser beam then heats the spot $(\sim 200 \mu \mathrm{m})$ in the capillary for typically $2-6{ }^{\circ} \mathrm{C}$. The IR laser creates the spatial distribution of temperature in the capillary and upon energy absorption, molecules drift usually from (positive thermophoresis) or more rarely towards (negative thermophoresis) heating beam (Figure 5). Since the fluorescence is excited through the same optical element as IR laser, the fluorescence detector then tracks the change in the emission of heated spot. It is possible to analyze and compare the differences in fluorescence before, between and after the heating of the solu-

Podobnik et al.: How to Study Protein-protein Interactions ... 
tion, since molecules possess different patterns of diffusion in the temperature field. There are two possibilities to observe fluorescence of the molecules. They can be labelled by fluorescent probes or their intrinsic fluorescence can be monitored. Fluorescence labelling proved to be most used method in MST, since conventional fluorescent detectors track low (nM, pM) concentrations of the labelled molecule. ${ }^{79}$ In addition, it is possible to track the molecules in complex solutions such as cell lysates or plasma. ${ }^{80}$ But on the other hand labelling with fluorescent tags, chemical dyes or artificial amino acids can influence the properties of the molecules and consequently the corresponding molecular interaction. For this reason "labelfree" MST, which analyses the fluorescence emission of natural amino acids such as tryptophan, gives an insight into the behavior of the molecule in the native state ${ }^{80}$ The potential drawbacks of label-free MST are that the solution of the molecule should be sufficiently pure and due to the lower fluorescence of natural residues the concentration of the molecule used in experiment is often higher compared to the analysis with the labeled molecules.

MST analyses proved to be optimal for investigating molecular interactions. If fluorescent molecule interacts with other parts of the system and interactions affect its mass, surface and/or hydration shelf, diffusion of the molecule alters along the thermal gradient. Therefore, by varying the concentration of e.g. ligand in the system and by comparing its influence on thermophoretic behavior of its fluorescently-labelled partner, stoichiometry of the inte- raction can be obtained. The MST showed to have a broad range of sensitivity. It has been shown that is possible to detect from $\mathrm{pM}$ to $\mathrm{mM}$ affinities of the protein-protein, protein-nucleic acid or nucleic acid-nucleic acid interactions or interactions of biomolecules with ions, lipids or small molecules. ${ }^{80}$ On the other hand also stability of the biomolecules can be analyzed using the same principle. ${ }^{81}$ If the environment affects the biomolecule's tertiary structure, its diffusion along the temperature gradient is also altered. Thus the MST behavior of fluorescent molecules can be screened against different salt concentrations, $\mathrm{pH}$, temperature or chemicals that have influence on its structure. Although the method is a novelty in the field of molecular interactions, it quickly showed its potential. Compared to the SPR, analyzing molecules are not attached to the surface and compared to the other methods, particularly ITC, low amounts of samples are used (Table 1). But yet, as thermophoretic behavior of the molecules is still not well understood, interpretation of MST might be quite complex and does not necessarily reflect the behavior of the molecules in natural environment.

\section{6. Molecular Interactions of Nanopores in Lipid Bilayers}

A biophysical approach that allows studying interactions of molecules with nanopores is termed planar lipid membranes (PLM), also called black lipid membranes (BLM) approach. ${ }^{82,83}$ BLM are artificial lipid bilayers,

\section{IR laser on}

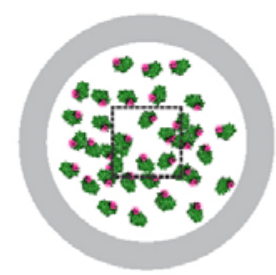

1

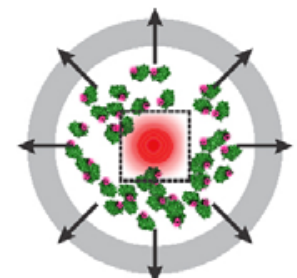

2

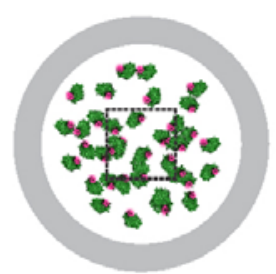

3

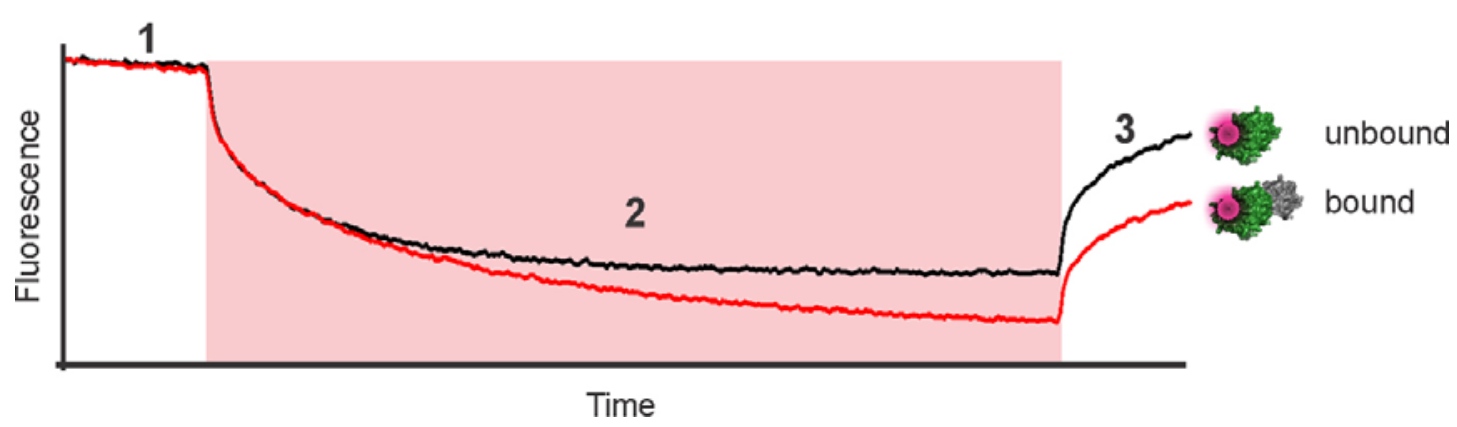

Figure 5. The MST experiment. The solution of molecules (green with magenta dots) is applied to the capillaries (grey circles). Following the initial fluorescence excitation of small fraction of the sample (dashed square) (1), the same part of the capillary is heated with IR laser (2). Upon heating, molecules usually drift away from the heating spot. The drift is observed as a reduction of the fluorescence. After turning the IR laser off, the back-diffusion of the molecules happens and this is detected as an increase of fluorescence (3). The bound and unbound molecules diffuse differently in the thermal field. 
enabling studies of properties of membrane active substances (e. g. channel proteins, pore forming proteins, DNA nanostructures) in a well-defined environment. This electrophysiological technique was introduced around 50 years ago and has gained enormous knowledge of biological membranes. ${ }^{82}$ It is used to estimate the pore/channel characteristics such as pore size, ionic selectivity, voltage dependence and transport of molecules through the pore (i.e. sensing) ${ }^{82-86}$ Variable molecules can be detected during passing through the pore and provide the information of the pore geometry or provide the useful kinetic data of the analyte. ${ }^{87}$ It is possible to screen various parameters that affect the pore characteristics, e.g. $\mathrm{pH}$, temperature, salt concentration, or voltage potential. ${ }^{83}$ Method enables variable interactions studies. It is possible to study the interactions of proteins with lipids and monitor the pore formation. With careful design and chemical modification insertions of DNA nanostructures into lipid bilayer are possible, resulting in artificial ion channel. ${ }^{88}$

BLM is a direct and label-free method that enables high resolution measurements in real time. The set up contains two small chambers (called cis and trans) separated with an aperture (diameter 50-160 $\mu \mathrm{m}$ ), where artificial planar lipid bilayers are formed and act as a capacitor. Chambers are filled with buffer and connected to an electronic system with $\mathrm{Ag}-\mathrm{AgCl}$ electrodes that permit the application of voltage at one side (usually the cis side) in range of tens of $\mathrm{mV},{ }^{83}$ while the trans side is grounded. With current-voltage amplifier we can measure changes in current fluctuations (in range of pico amperes) caused by incorporation of pores into the membrane. Each single pore can be detected as an increase or decrease in the cur- rent, depending on the sign of voltage, where pore insertion reflects as an step-like current change. ${ }^{83}$ From ionic current through the membrane (I) and the applied transmembrane potential (V) it is possible to calculate the conductance $(\mathrm{G})$ by simple equation of $\mathrm{G}(\mathrm{nS})=\mathrm{I}(\mathrm{pA}) / \mathrm{V}$ $(\mathrm{mV}) .{ }^{89}$ Usually very low amount of membrane active substances (in range of ato- to nano molar) are needed to reconstitute into the membrane and to enable monitoring of their functional characteristics. Nowadays methods offer parallel high-resolution recordings with automatic bilayer formation and mostly software measurement processing. 84

In past decades a variable workload from pore sensing to the nanopore-based detector for the DNA or RNA sequencings has been done on $\alpha$-hemolysin $(\alpha \mathrm{HL})$, an exotoxin from bacterium Staphylococcus aureus. ${ }^{87,90-92}$ $\alpha H L$ monomers self-assemble on lipid bilayers to a heptameric pore and form app. $100 \AA$ long channel. ${ }^{90}$ A wide range of molecules have been tested in sensing experiments to gain the data of the concentration and quantification of the analyte (Figure 6). ${ }^{87}$ The pore was also mutated to acquire better DNA bases recognition ${ }^{92}$ and to provide more controllable environment to delivery of ligands.

\section{Structural Approaches for Describing Molecular Interactions}

\section{1. X-ray Crystallography}

Three dimensional structures of molecular interactions at atomic resolution can be measured by X-ray cry-

A
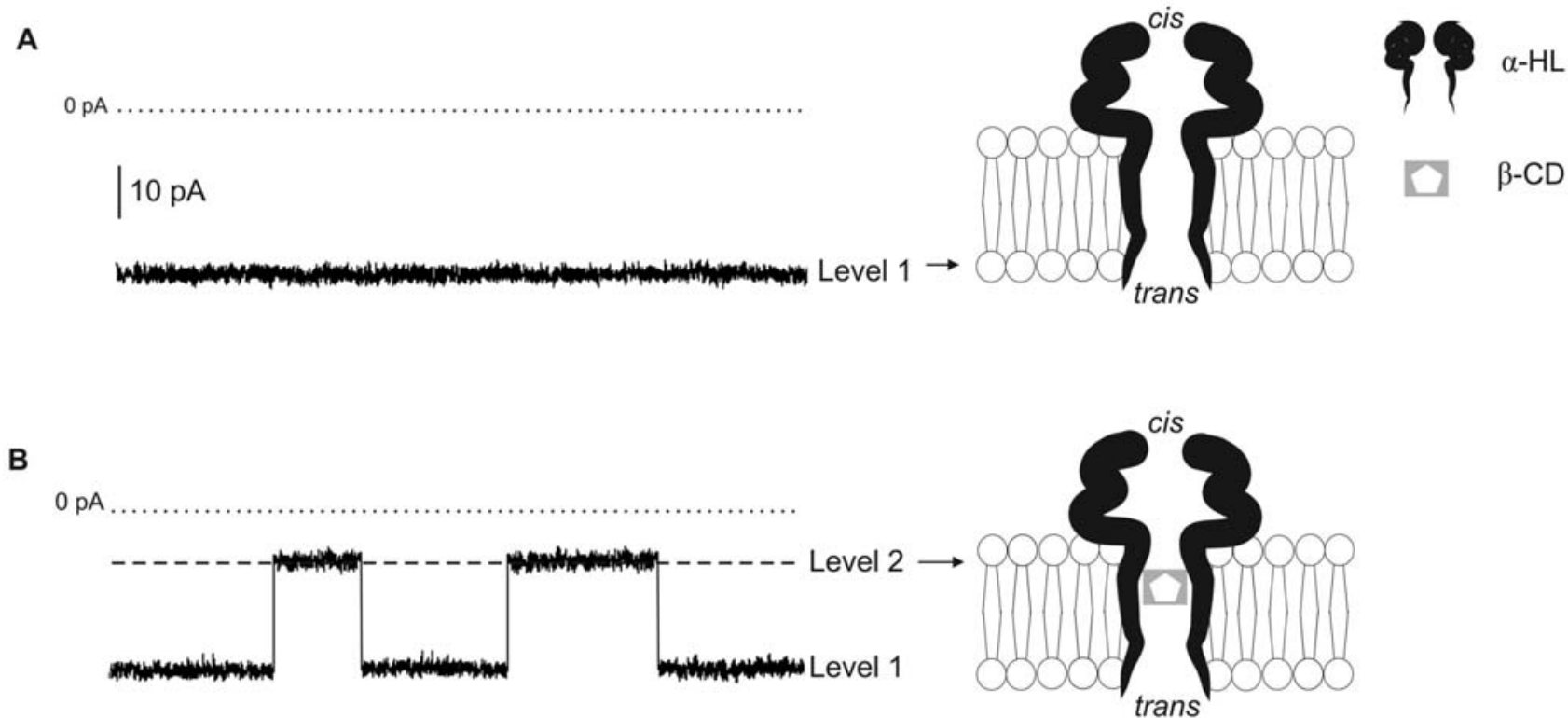

Figure 6. Black lipid membranes recordings of single $\alpha$-hemolysin $(\alpha$-HL) pore with $\beta$-cyclodextrin $(\beta C D)$. Currents were recorded at $-40 \mathrm{mV}$ ( cis at ground). $\alpha$-HL pore was entering from the cis side and $\beta C D$ from the trans side. (A) Single a-HL pore constantly open at around -30 pA (level 1); (B) $\beta C D$ partially blocking the channel at around $10 \mathrm{pA}$ (level 2). Adapted from Gu et al. ${ }^{91}$ with permission. 
stallography, nuclear magnetic resonance spectroscopy (NMR) and with dramatic recent developments also with cryo-electron microscopy (cryo-EM). Of these, X-ray crystallography is the most popular as well as practical, since it can give atomic resolution structural information on a broad range of molecules, namely from small molecules to macromolecules, including proteins, nucleic acids and large cellular complexes, like ribosomes, proteasomes or viruses. Consequently, it has also been a primary method for deducing structural details of molecular interactions. Of the more than 110,000 released entries in the Protein Data Bank, about $90 \%$ were solved by this technique. ${ }^{93}$ Crystal structure determination involves preparation of protein samples of high purity, homogeneity and stability, crystallization of these molecules, collection of X-ray diffraction data, structure solution, model building, and refinement. The principle of this method is that X-rays scatter on protein electrons as they pass through a protein crystal. The scattered waves interfere with each other, resulting in a diffraction pattern from which the positions of atoms and thus three dimensional structure of proteins is determined (Figure 7). Further analysis of structural features helps understand biological roles and mechanism of action of molecules under study. ${ }^{94}$

However, a care has to be taken when studying macromolecular complexes, since a crystal structure of a complex might not reveal a unique binding interface. Determination of a biological interface from crystal contacts may not be straightforward and unambiguous. ${ }^{95} \mathrm{Im}$ portantly, macromolecular crystals mostly grow under non-physiological conditions, including high protein concentrations, a wide range of $\mathrm{pH}$ values and temperature, high ionic strength, or in the presence of various non-biological compounds that aid crystallization. This can result in intermolecular contacts that are not biologically relevant, or the crystallization of what is expected to be a complex in a solution may not result in the crystal containing all subunits of the complex. ${ }^{95}$

Due to these potentially harsh and non-natural crystallization conditions, complexes between molecules with high affinity have higher chances to actually crystallize as functional complexes, as in the case of proteins Vps29 and Vps35, forming a subcomplex of the retromer cargo-recognition complex with $\mathrm{K}_{\mathrm{D}}$ of $350 \mathrm{n}$ M. ${ }^{96,97}$ The same is true for high affinity complexes between proteins and small ligands, as for example tight binding of GMP in the active site of the metallophosphodiesterase MPPED2. ${ }^{98}$ For weaker interactions in high micromolar or even millimolar ranges, combination with NMR and small angle X-ray scattering (SAXS ) is a better choice. ${ }^{99,100}$ However, under certain conditions and especially in a high excess of ligands, crystals structure of very low affinity (i.e. millimolar range) complexes can be obtained, like in the case of a mannose binding by pneumolysin. ${ }^{101}$
A

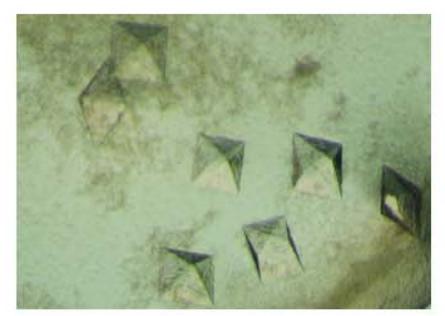

B

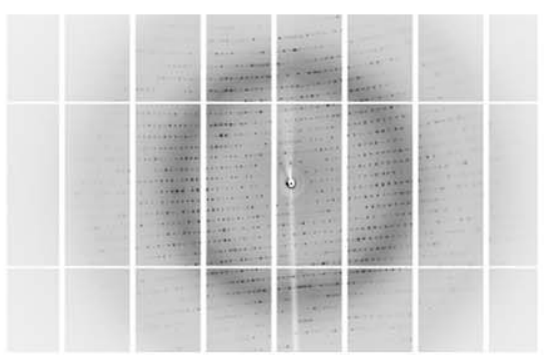

$\mathrm{C}$

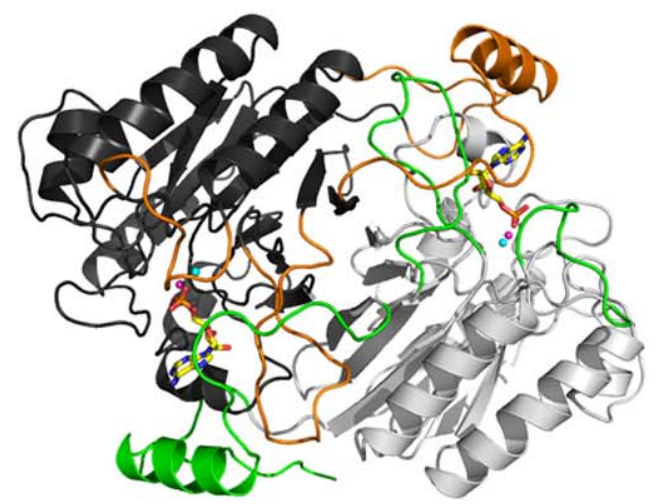

D

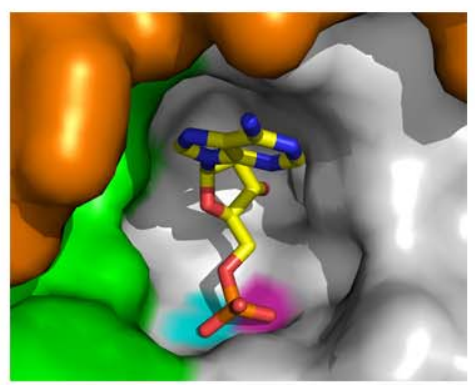

Figure 7. From crystals to structure: (A) Protein crystals. (B) X-ray diffraction data obtained at the synchrotron X-ray source. (C) Crystal structures often reveal details of protein complex with smaller ligands. Here, structure of metallophosphodiesterase Rv0805 homodimer from Mycobacterium tuberculosis in complex with AMP is shown. ${ }^{102}$ (D) the same as in (C), showing the surface of the active site and the bound AMP molecule in sticks.

\section{2. Nuclear Magnetic Resonance Spectroscopy}

NMR spectroscopy is the second most powerful and predominant technique used to experimentally determine 
three-dimensional structures of biological macromolecules at near atomic resolution, where samples are measured in soluble state. NMR is usually used in cases where no protein crystals can be obtained, and in contrast to crystallography, it also provides information on solution state dynamics. Generally, NMR generates lower resolution structures than X-ray crystallography and is limited to molecular weights below $50 \mathrm{kDa} .{ }^{103}$ However, NMR can be used as a complementary method to X-ray crystallography, representing a great alternative in the case of transient macromolecular complexes, which refuse to crystallize in high quality crystals, or when crystals do not contain the biologically relevant conformation of the proteins. In cases where the interaction is weak $\left(\mathrm{K}_{\mathrm{D}}>100 \mathrm{mM}\right)$, NMR is essentially the only approach that allows the determination of high-resolution structures. ${ }^{99}$

The basis of NMR spectroscopy is the property of many elements to have a nuclear magnetic moment. Stable isotopes of particular importance in biological macromolecules are ${ }^{1} \mathrm{H},{ }^{13} \mathrm{C}$, or ${ }^{15} \mathrm{~N}$. When placed into a static magnetic field (B), the different nuclear spin states of these nuclei become quantized with energies proportional to their projection onto B. The energy difference depends on the type of nucleus, is proportional to field strength of the static magnet, and is dependent on the chemical environment of the nucleus. This energy difference corresponds to electromagnetic radiation in the megahertz range. The transition between these states can be induced by irradiation with a radio-frequency field with characteristic frequencies for each type of nucleus and its chemical environment. The frequency of the NMR signal is extremely sensitive towards changes in covalent bonds, i.e. presence of neighboring groups, as well as to noncovalent bonding found in complexes built by biological macromolecules. Furthermore, transfer of magnetization through bonds or through space results in a characteristic change of the shape and size of the NMR signal and reflects, for example, the bond angle in the case of scalar coupling or spatial distance in the case of dipolar coupling. Various NMR experimental approaches are available to observe these phenomena, and the resulting spectra can provide structural details about the interactions between partner molecules under study. ${ }^{104}$

There are several approaches in NMR by which the interaction of biological macromolecules and low molecular weight-ligands can be characterized at an atomic level, using relatively quick and easy ligand-based techniques. These need only small amounts of nonisotope labeled, and thus readily available target macromolecules. As the focus is on the signals stemming only from the ligand, no further NMR information regarding the target is needed. Techniques based on the observation of isotopically labeled biological macromolecules open the possibility to observe interactions of proteins with low-molecularweight ligands, DNA or other proteins. With these techniques, the structure of high-molecular-weight complexes can be determined. In this case, the resonance signals of the macromolecule must be identified beforehand. ${ }^{104}$ The NMR-based procedures can be roughly subdivided into two groups: (1) observation of the NMR signals of the usually low molecular weight-ligand and its behavior upon binding to the target, and (2) focus on the signals of the usually much higher molecular weight protein or DNA target and the effect of the binding ligand. The former relies on the transfer of magnetization between target and bound ligand giving rise to ligand signals, whereas the latter observes the effect of ligand binding on the chemical shift of the target resonances, thus changing the position of the target NMR signals. One big advantage of NMR measurements is that the experiments are performed in aqueous solutions, that can be relatively close to biological conditions. ${ }^{104}$

The available NMR methods for studying interactions are, to name some: intermolecular dipole-dipole relaxation effect, cross-saturation, chemical shift perturbation, dynamics and exchange perturbation, paramagnetic methods, and dipolar orientation. Most of these methods have been used to study complexes with molecular weight of $60 \mathrm{kDa}$ and can be used also for large complexes, up to $1000 \mathrm{kDa}^{99,105,106}$ Advances in instrumentation have enabled to overcome the classical size-limitation of solution-state NMR and have demonstrated its use in studies of mega-dalton protein complexes, including those containing nucleic acids. ${ }^{105,107,108}$ Furthermore, solid-state NMR (ssNMR) has emerged in the last decade as one of the prominent methods to study the structure of large, poorly soluble molecules, especially of membrane proteins and intrinsically disordered proteins. ${ }^{105}$

\section{3. Cryo-electron Microscopy}

Cryo-electron microscopy (cryo-EM) is increasingly becoming a mainstream technology for studying the architecture of cells, viruses and protein assemblies at molecular and even atomic resolution. For many years, structure determination of biological macromolecules by cryo-EM was limited to large complexes and low-resolution models. Recent developments in microscope design and imaging hardware, in combination with enhanced image processing and automation, build the crucial basis for further advance of cryo-EM method, which are approaching resolutions obtained by X-ray crystallography, and are becoming applicable also for smaller molecular objects. Experimentation at cryogenic temperatures and averaging of multiple low-dose images are central to modern high-resolution biological electron microscopy. ${ }^{93,109}$

In Cryo-EM set-up, a frozen protein solution is exposed to a beam of electrons. The electrons scattered by the sample pass through a lens that creates a magnified image on the detector, from which the structure can be deduced. ${ }^{93}$ Cryo-EM can be divided in several subdisciplines, including cryo-electron tomography, single-particle 
cryo-EM, and electron crystallography. These methods can be used singly as well as in hybrid approaches, where the information from cryo-EM is combined with complementary information obtained using X-ray crystallography or NMR. ${ }^{109}$ Cryo-electron tomography is emerging as a powerful method to visualize structurally heterogeneous objects (e.g. viruses, tissues, cellular and sub-cellular multimolecular assemblies) at resolutions between $100 \AA$ and $\sim 50 \AA$ and reaching up to $20 \AA$ and higher, when applying subvolume averaging. ${ }^{109}$ Single-particle cryo-EM is probably the most commonly used variant of cryo-EM. In this case, data from a large number of $2 \mathrm{D}$ projection images, featuring identical copies of a protein complex in different orientations, are combined to generate a 3D reconstruction of the structure. Following this, atomic models, available for some or all of the components building the complex are fitted into the density map to provide pseudo-atomic models, which largely extends the information obtained by electron microscopy ${ }^{109}$ Using this approach, resolutions beyond $3 \AA$ can be achieved now, as a combination of a technical development, as well as sample preparation improvement. ${ }^{93,109,110}$ Cryo-electron microscopy of ordered assemblies or electron crystallography allows even higher resolutions due to highly crystalline assemblies, forming two-dimensional crystals or other types of ordered assemblies such as tubular crystals and helical assemblies. ${ }^{109}$ This strategy has been extremely effective with membrane proteins that form two-dimensional crystals in the plane of the membrane, and high resolutions, reaching beyond $1.8 \AA$ have been reported. ${ }^{109,111}$ The drawback here is that proteins have to be amenable to form ordered assemblies such as helical or two-dimensional crystals.

Besides using Cryo-EM approach as a method of a choice to study huge and dynamic complexes, molecular machines like ribosomes, viruses and membrane proteins, it can be also used to calculate the structure of a protein that has been flash-frozen in several conformations to deduce the mechanisms by which it works. ${ }^{93}$ Thus, electron microscopy has the potential to provide both structural and dynamic information of biological assemblies in order to understand the molecular mechanisms of their functions. ${ }^{112}$

\section{Conclusions}

Complementary structural, biophysical, functional and computational methods should be considered in order to correctly describe and interpret macromolecular interactions in biological systems. In many cases this means employing different protein constructs and complementary approaches. These may in addition to those described in this review include SAXS, neutron and light scattering, atomic force microscopy, mass spectrometry and analytical ultracentrifugation, which yield information on the shape, size and mass of macromolecules. Chemical crosslinking and electron paramagnetic resonance can yield data on proximities of different parts of macromolecules, while circular dichroism informs about the secondary structural content of a protein. Furthermore, mutational analysis of the potential binding interfaces in combination with methods that measure the strength of binding in wild type and in mutated proteins, like ITC, SPR and MST, give further details on correctness of determined interfaces by structural methods, such as X-ray crystallography. Novel approaches, developments in instrumentation and advances in protein recombinant technology will allow better and more rapid description of molecular interactions for many important biological molecules.

\section{Acknowledgements}

We would like to thank for the financial support to the Slovenian Research Agency (Program grant Molecular Interactions P1-039 and Network of Research Infrastructural Programs of the University of Ljubljana I00022). We dedicate this paper to the memory of prof. Janko Jamnik, who unreservedly supported our efforts towards excellence in studying molecular interactions.

\section{References}

1. I. Petta, S. Lievens, C. Libert, J. Tavernier, K. De Bosscher, Mol. Therapy 2015, doi: 10.1038/mt.2015.214. http://dx.doi.org/10.1038/mt.2015.214

2. A. M. Watkins, P. S. Arora, Eur. J. Med. Chem. 2015, 94, 480-488.

3. P. Wojcik, L. Berlicki, Bioorg. Med. Chem. Lett. 2016, 26, 707-713.

4. L. G. Milroy, T. N. Grossmann, S. Hennig, L. Brunsveld, C. Ottmann, Chem. Rev. 2014, 114, 4695-4748.

5. O. Byron, B. Vestergaard, Curr. Opin. Struct. Biol. 2015, 35, 76-86.

6. A. Perrakis, A. Musacchio, S. Cusack, C. Petosa, J. Struct. Biol. 2011, 175, 106-112.

7. J. R. Perkins, I. Diboun, B. H. Dessailly, J. G. Lees, C. Orengo, Structure 2010, 18, 1233-1243.

8. I. Wittig, H. Schagger, Proteomics 2009, 9, 5214-5223.

9. F. E. Paul, F. Hosp, M. Selbach, Methods 2011, 54, 387-395.

10. N. Johnsson, Biochem. Biophys. Res. Commun. 2014, 445, 739-745.

11. D. M. Fowler, J. J. Stephany, S. Fields, Nature Protocols 2014, 9, 2267-2284.

12. O. Puig, F. Caspary, G. Rigaut, B. Rutz, E. Bouveret, E. Bragado-Nilsson, M. Wilm, B. Seraphin, Methods 2001, 24, 218-229.

13. P. Kaiser, D. Meierhofer, X. Wang, L. Huang, Methods Mol. Biol. 2008, 439, 309-326.

14. N. J. Krogan, G. Cagney, H. Yu, G. Zhong, X. Guo, A. Ig- 
natchenko, J. Li, S. Pu, N. Datta, A. P. Tikuisis, T. Punna, J. M. Peregrin-Alvarez, M. Shales, X. Zhang, M. Davey, M. D. Robinson, A. Paccanaro, J. E. Bray, A. Sheung, B. Beattie, D. P. Richards, V. Canadien, A. Lalev, F. Mena, P. Wong, A. Starostine, M. M. Canete, J. Vlasblom, S. Wu, C. Orsi, S. R. Collins, S. Chandran, R. Haw, J. J. Rilstone, K. Gandi, N. J. Thompson, G. Musso, P. St Onge, S. Ghanny, M. H. Lam, G. Butland, A. M. Altaf-Ul, S. Kanaya, A. Shilatifard, E. O'Shea, J. S. Weissman, C. J. Ingles, T. R. Hughes, J. Parkinson, M. Gerstein, S. J. Wodak, A. Emili, J. F. Greenblatt, Nature 2006, 440, 637-643.

15. J. H. Morris, G. M. Knudsen, E. Verschueren, J. R. Johnson, P. Cimermancic, A. L. Greninger, A. R. Pico, Nature Protocols 2014, 9, 2539-2554.

16. M. L. Valero, R. Sendra, M. Pamblanco, J. Proteomics 2016, doi: 10.1016/j.jprot.2016.01.004. http://dx.doi.org/10.1016/j.jprot.2016.01.004

17. J. Van Leene, D. Eeckhout, B. Cannoot, N. De Winne, G. Persiau, E. Van De Slijke, L. Vercruysse, M. Dedecker, A. Verkest, K. Vandepoele, L. Martens, E. Witters, K. Gevaert, G. De Jaeger, Nature Protocols 2015, 10, 169-187.

18. A. M. Edwards, B. Kus, R. Jansen, D. Greenbaum, J. Greenblatt, M. Gerstein, Trends Genet. 2002, 18, 529-536.

19. W. H. Dunham, M. Mullin, A. C. Gingras, Proteomics 2012, 12, 1576-1590.

20. J. H. Caufield, N. Sakhawalkar, P. Uetz, Methods 2012, 58, 317-324.

21. A. Bruckner, C. Polge, N. Lentze, D. Auerbach, U. Schlattner, Int. J. Mol. Sci. 2009, 10, 2763-2788.

22. J. Mehla, J. H. Caufield, P. Uetz, Cold Spring Harbor Protocols 2015, 2015, 442-452.

23. B. Deplancke, D. Dupuy, M. Vidal, A. J. Walhout, Genome Res. 2004, 14, 2093-2101.

24. D. J. SenGupta, B. Zhang, B. Kraemer, P. Pochart, S. Fields, M. Wickens, Proc. Natl. Acad. Sci. USA 1996, 93, 84968501.

25. I. Štagljar, C. Korostensky, N. Johnsson, S. te Heesen, Proc. Natl. Acad. Sci. USA 1998, 95, 5187-5192.

26. K. Zolghadr, O. Mortusewicz, U. Rothbauer, R. Kleinhans, H. Goehler, E. E. Wanker, M. C. Cardoso, H. Leonhardt, Mol. Cell. Proteomics 2008, 7, 2279-2287.

27. S. Lievens, S. Gerlo, I. Lemmens, D. J. De Clercq, M. D. Risseeuw, N. Vanderroost, A. S. De Smet, E. Ruyssinck, E. Chevet, S. Van Calenbergh, J. Tavernier, Mol. Cell. Proteomics 2014, 13, 3332-3342.

28. J. F. Rual, K. Venkatesan, T. Hao, T. Hirozane-Kishikawa, A. Dricot, N. Li, G. F. Berriz, F. D. Gibbons, M. Dreze, N. Ayivi-Guedehoussou, N. Klitgord, C. Simon, M. Boxem, S. Milstein, J. Rosenberg, D. S. Goldberg, L. V. Zhang, S. L. Wong, G. Franklin, S. Li, J. S. Albala, J. Lim, C. Fraughton, E. Llamosas, S. Cevik, C. Bex, P. Lamesch, R. S. Sikorski, J. Vandenhaute, H. Y. Zoghbi, A. Smolyar, S. Bosak, R. Sequerra, L. Doucette-Stamm, M. E. Cusick, D. E. Hill, F. P. Roth, M. Vidal, Nature 2005, 437, 1173-1178.

29. H. Yu, L. Tardivo, S. Tam, E. Weiner, F. Gebreab, C. Fan, N. Svrzikapa, T. Hirozane-Kishikawa, E. Rietman, X. Yang, J.
Sahalie, K. Salehi-Ashtiani, T. Hao, M. E. Cusick, D. E. Hill, F. P. Roth, P. Braun, M. Vidal, Nature Methods 2011, 8, 478-480.

30. T. Forster: Delocalized excitation and excitation transfer. In Modern Quantum Chemistry. Vol. 3.; Sinanoglu, E., Ed.; Academic Press: New York, 1965; pp 93-137.

31. A. Pietraszewska-Bogiel, T. W. Gadella, J. Microscopy 2011, 241, 111-118.

32. A. Hoppe, K. Christensen, J. A. Swanson, Biophys J. 2002, $83,3652-3664$.

33. A. D. Hoppe, B. L. Scott, T. P. Welliver, S. W. Straight, J. A. Swanson, PLoS ONE 2013, 8, e64760.

34. A. J. Garcia-Saez, S. B. Buschhorn, H. Keller, G. Anderluh, K. Simons, P. Schwille, J. Biol. Chem. 2011, 286, 3776837777.

35. M. Skočaj, B. Bakrač, I. Križaj, P. Maček, G. Anderluh, K. Sepčić, Curr. Med. Chem. 2013, 20, 491-501.

36. P. Schuck, Annu. Rev. Biophys. Biomol. Struct. 1997, 26, 541-566.

37. R. L. Rich, D. G. Myszka, J. Mol. Recognit. 2011, 24, 892914.

38. N. J. de Mol, M. J. E. Fischer: Surface Plasmon Resonance: Methods and Protocols; Humana Press: New York, USA, 2010; Vol. 627.

39. V. Godinic-Mikulčić, J. Jarić, C. D. Hausmann, M. Ibba, I. Weygand-Đurašević, J. Biol. Chem. 2011, 286, 3396-3404.

40. B. Bakrač, A. Kladnik, P. Maček, G. McHaffie, A. Werner, J. H. Lakey, G. Anderluh, J. Biol. Chem. 2010, 285, 2218622195.

41. A. Bavdek, R. Kostanjšek, V. Antonini, J. H. Lakey, M. Dalla Serra, R. J. Gilbert, G. Anderluh, FEBS J. 2012, 279, 126141.

42. M. Beseničar, P. Maček, J. H. Lakey, G. Anderluh, Chem. Phys. Lipids 2006, 141, 169-178.

43. M. Brvar, A. Perdih, V. Hodnik, M. Renko, G. Anderluh, R. Jerala, T. Šolmajer, Bioorg. Med. Chem. 2012, 20, 25722580.

44. V. Škedelj, E. Arsovska, T. Tomašić, A. Kroflič, V. Hodnik, M. Hrast, M. Bešter-Rogač, G. Anderluh, S. Gobec, J. Bostock, I. Chopra, A. J. O'Neill, C. Randall, A. Žega, PLoS ONE 2012, 7, e39922.

45. V. Kodoyianni, Biotechniques 2011, 50, 32-40.

46. N. F. Visser, A. J. Heck, Expert Rev. Proteomics 2008, 5, 425-433.

47. Q. Zhang, L. Jing, J. Zhang, Y. Ren, Y. Wang, T. Wei, B. Liedberg, Anal. Biochem. 2014, 463, 7-14.

48. S. Kumar, N. Dilbaghi, M. Barnela, G. Bhanjana, R. Kumar, BioNanoScience 2012, 2, 196-217.

49. V. Hodnik, G. Anderluh, Sensors (Basel) 2009, 9, 13391354.

50. J. Zhang, Y. Sun, B. Xu, H. Zhang, Y. Gao, D. Song, Biosens. Bioelectron. 2013, 45, 230-236.

51. M. Dysinger, L. E. King, J. Immunol. Meth. 2012, 379, 3041.

52. N. B. Shah, T. M. Duncan, J. Vis. Exp. 2014, e51383.

53. A. Sultana, J. E. Lee, Curr. Protocols Prot. Sci. 2015, 79, 1925. 
54. J. Wallner, G. Lhota, D. Jeschek, A. Mader, K. Vorauer-Uhl, J. Pharm. Biomed. Anal. 2013, 72, 150-154.

55. M. M. Pierce, C. S. Raman, B. T. Nall, Methods 1999, 19, 213-221.

56. M. Podobnik, T. F. Weitze, M. O’Donnell, J. Kuriyan, Structure 2003, 11, 253-263.

57. S. Rinaldo, A. Paiardini, V. Stelitano, P. Brunotti, L. Cervoni, S. Fernicola, C. Protano, M. Vitali, F. Cutruzzola, G. Giardina, J. Bacteriol. 2015, 197, 1525-1535.

58. R. Ghai, R. J. Falconer, B. M. Collins, J. Mol. Recognit. 2012, 25, 32-52.

59. P. Draškovič: Biochemical and structural analysis of the catalytic versatility of the mammalian inositol hexakisphosphate kinase isoforms, PhD Thesis, University of Ljubljana, 2009.

60. K. A. Marx, Biomacromolecules 2003, 4, 1099-1120.

61. Q. Chen, S. Xu, Q. Liu, J. Masliyah, Z. Xu, Adv. Colloid Int. Sci. 2015, doi: 10.1016/j.cis.2015.10.004. http://dx.doi.org/10.1016/j.cis.2015.10.004

62. K. Kanazawa, N. Cho, J. Sensors 2009, 2009, 824947.

63. E. Nileback, F. Westberg, J. Deinum, S. Svedhem, Anal. Chem. 2010, 82, 8374-8376.

64. M. M. Ayad, N. Prastomo, A. Matsuda, J. Stejskal: Sensing of silver ions by nanotubular polyaniline film deposited on quartz-crystal in a microbalance. In Synthetic Metals, vol. 160; Apodaca, 2010; pp 42-46.

65. D. C. Apodaca, R. B. Pernites, R. R. Ponnapati, F. R. Del Mundo, R. C. Advincula, ACS App. Mat. Interfaces 2011, 3, 191-203.

66. N. J. Cho, K. H. Cheong, C. Lee, C. W. Frank, J. S. Glenn, J. Virol. 2007, 81, 6682-6689.

67. J. Iturri, L. Garcia-Fernandez, U. Reuning, A. J. Garcia, A. del Campo, M. J. Salierno, Sci. Rep. 2015, 5, 9533.

68. L. Al-Halabi, A. Balck, M. Michalzik, D. Frode, S. Buttgenbach, M. Hust, T. Schirrmann, S. Dubel, $m A$ bs 2013, 5, 140-149.

69. A. Makino, M. Abe, M. Murate, T. Inaba, N. Yilmaz, F. Hullin-Matsuda, T. Kishimoto, N. L. Schieber, T. Taguchi, H. Arai, G. Anderluh, R. G. Parton, T. Kobayashi, FASEB J. 2015, 29, 477-493.

70. S. Cabric, J. Sanchez, U. Johansson, R. Larsson, B. Nilsson, O. Korsgren, P. U. Magnusson, Tissue Eng. 2010, 16, 961970 .

71. D. Stratton, S. Lange, S. Kholia, S. Jorfi, S. Antwi-Baffour, J. Inal, Biochem. Biophys. Res. Commun. 2014, 453, 619- 624.

72. D. Peiris, M. Ossondo, S. Fry, M. Loizidou, J. Smith-Ravin, M. V. Dwek, PLoS ONE 2015, 10, e0138345.

73. J. P. Severinghaus, T. Sowers, E. J. Brook, R. B. Alley, M. L. Bender, Nature 1998, 391, 141-146.

74. J. Rauch, W. Kohler, Phys. Rev. Lett. 2002, 88, 185901.

75. F. Huang, P. Chakraborty, C. C. Lundstrom, C. Holmden, J. J. Glessner, S. W. Kieffer, C. E. Lesher, Nature 2010, 464, 396-400.

76. D. Braun, A. Libchaber, Phys. Rev. Lett. 2002, 89, 188103.

77. P. Baaske, C. J. Wienken, P. Reineck, S. Duhr, D. Braun, Angew. Chem. Int. Ed. Engl. 2010, 49, 2238-2241.
78. C. J. Wienken, P. Baaske, U. Rothbauer, D. Braun, S. Duhr, Nature Comm. 2010, 1, 100.

79. M. Jerabek-Willemsen, C. J. Wienken, D. Braun, P. Baaske, S. Duhr, Assay Drug Dev. Technol. 2011, 9, 342-353.

80. S. A. Seidel, P. M. Dijkman, W. A. Lea, G. van den Bogaart, M. Jerabek-Willemsen, A. Lazic, J. S. Joseph, P. Srinivasan, P. Baaske, A. Simeonov, I. Katritch, F. A. Melo, J. E. Ladbury, G. Schreiber, A. Watts, D. Braun, S. Duhr, Methods 2013, 59, 301-315.

81. C. G. Alexander, R. Wanner, C. M. Johnson, D. Breitsprecher, G. Winter, S. Duhr, P. Baaske, N. Ferguson, Biochim. Biophys. Acta 2014, 1844, 2241-2250.

82. M. Winterhalter, Curr. Opin. Colloid Interface Sci. 2000, 5, 250-255.

83. M. Marchioretto, M. Podobnik, M. Dalla Serra, G. Anderluh, Biophys. Chem. 2013, 182, 64-70.

84. C. Weichbrodt, H. Bajaj, G. Baaken, J. Wang, S. Guinot, M. Kreir, J. C. Behrends, M. Winterhalter, N. Fertig, Analyst 2015, 140, 4874-4881.

85. G. Anderluh, M. Dalla Serra, G. Viero, G. Guella, P. Maček, G. Menestrina, J. Biol. Chem. 2003, 278, 45216-45223.

86. T. Praper, A. Sonnen, G. Viero, A. Kladnik, C. J. Froelich, G. Anderluh, M. Dalla Serra, R. J. Gilbert, J. Biol. Chem. 2011, 286, 2946-2955.

87. H. Bayley, P. S. Cremer, Nature 2001, 413, 226-230.

88. M. Langecker, V. Arnaut, J. List, F. C. Simmel, Acc. Chem. Res. 2014, 47, 1807-1815.

89. M. Podobnik, M. Marchioretto, M. Zanetti, A. Bavdek, M. Kisovec, M. M. Cajnko, L. Lunelli, M. Dalla Serra, G. Anderluh, Sci. Rep. 2015, 5, 9623.

90. L. Song, M. R. Hobaugh, C. Shustak, S. Cheley, H. Bayley, J. E. Gouaux, Science 1996, 274, 1859-1866.

91. L. Q. Gu, O. Braha, S. Conlan, S. Cheley, H. Bayley, Nature 1999, 398, 686-690.

92. M. Ayub, D. Stoddart, H. Bayley, ACS Nano 2015, 9, 7895-7903.

93. E. Callaway, Nature 2015, 525, 172-174.

94. J. Drenth: Principles of Protein X-Ray Crystallography; Spronger-Verlag: New York, 2007.

95. B. Kobe, G. Gunčar, R. Buchholz, T. Huber, B. Maco, N. Cowieson, J. L. Martin, M. Marfori, J. K. Forwood, Biochem. Soc. Trans. 2008, 36, 1438-1441.

96. A. Hierro, A. L. Rojas, R. Rojas, N. Murthy, G. Effantin, A. V. Kajava, A. C. Steven, J. S. Bonifacino, J. H. Hurley, Nature 2007, 449, 1063-1067.

97. B. M. Collins, C. F. Skinner, P. J. Watson, M. N. Seaman, D. J. Owen, Nature Struct. Mol. Biol. 2005, 12, 594-602.

98. U. Dermol, V. Janardan, R. Tyagi, S. S. Visweswariah, M. Podobnik, J. Mol. Biol. 2011, 412, 481-494.

99. M. R. O'Connell, R. Gamsjaeger, J. P. Mackay, Proteomics 2009, 9, 5224-5232.

100. A. T. Tuukkanen, D. I. Svergun, FEBS J. 2014, 281, 19741987.

101. S. A. Park, Y. S. Park, S. M. Bong, K. S. Lee, J. Struct. Biol. 2016, 193, 132-140.

102. M. Podobnik, R. Tyagi, N. Matange, U. Dermol, A. K. 
Gupta, R. Mattoo, K. Seshadri, S. S. Visweswariah, J. Biol. Chem. 2009, 284, 32846-32857.

103. V. V. Krishnan, B. Rupp, eLS 2012.

104. T. Maurer: NMR Studies of Protein-Ligand Interactions. In Protein-Ligand Interactions; Ulrich Nienhaus, G., Ed.; Humana Press: Totowa, NJ, 2005; pp 197-213.

105. T. Carlomagno, J. Magn. Reson. 2014, 241, 126-136.

106. E. R. Zuiderweg, Biochemistry 2002, 41, 1-7.

107. I. J. Griswold, F. W. Dahlquist, Nature Struct. Biol. 2002, 9 , 567-568.
108. A. Mainz, T. L. Religa, R. Sprangers, R. Linser, L. E. Kay, B. Reif, Angew. Chem. Int. Ed. Engl. 2013, 52, 8746-8751.

109. J. L. Milne, M. J. Borgnia, A. Bartesaghi, E. E. Tran, L. A. Earl, D. M. Schauder, J. Lengyel, J. Pierson, A. Patwardhan, S. Subramaniam, FEBS J. 2013, 280, 28-45.

110. A. Bartesaghi, A. Merk, S. Banerjee, D. Matthies, X. Wu, J. L. Milne, S. Subramaniam, Science 2015, 348, 1147-1151.

111. T. Gonen, Y. Cheng, P. Sliz, Y. Hiroaki, Y. Fujiyoshi, S. C. Harrison, T. Walz, Nature 2005, 438, 633-638.

112. A. Durand, G. Papai, P. Schultz, J. Nanobiotechnol. 2013, $11, \mathrm{~S} 4$.

\section{Povzetek}

Fizične in funkcionalne interakcije med molekulami imajo osrednjo vlogo pri vseh bioloških procesih v živih sistemih. Identifikacija proteinskih kompleksov postaja za razumevanje celic in organizmov na molekularni ravni vedno bolj pomembna. V zadnjih letih je bilo razvitih več učinkovitih metod in tehnik za raziskave molekulskih interakcij, ki pomagajo osvetliti njihov pomen v biologiji, kot tudi možne načine preprečevanja interakcij med njimi. Vse tehnike, ki so na voljo za te študije, imajo svoje prednosti in slabosti, in ker jih večinoma uporabimo v pogojih in vitro, težko z enim samim pristopom učinkovito sledimo vsem interakcijam, ki se zgodijo pri fizioloških pogojih. Z dopolnjujočo uporabo več razpoložljivih tehnik lahko ustvarimo realistično sliko biološkega procesa. V prispevku bomo opisali nekaj proteomskih, biofizikalnih in strukturnih orodij, ki nam pomagajo razumeti naravo in mehanizem teh interakcij. 